\title{
Pengaruh Kualitas Pelayanan Terhadap Kepuasan Pelanggan PT. Langit Membiru Wisata Bogor
}

\author{
Rini Ardista \\ Sekolah Tinggi Ilmu Ekonomi Tribuana \\ riniardista27@gmail.com
}

\begin{abstract}
This research aims to determine and analyze the effect of service quality on customer satisfaction of PT. Langit Membiru Wisata Bogor, to find out how big the influence and relationship between service quality and customer satisfaction. The sample used was 100 respondents taken through t-test or interviews, observations, and questionnaires at PT. Langit Membiru Wisata Bogor and the primary data source processed with SPSS 25. The t-test results show the effect of service quality on customer satisfaction, this is evidenced by the variable $(X)$ service quality and variable $(Y)$ customer satisfaction has a value less than 0.05, namely $(0.00<0.05)$, this is proven with the value in the t test obtained $t$ count 91.624> t table 5.293, so it can be concluded that the hypothesis can be accepted.
\end{abstract}

Keyword : Service Quality, Customer Satisfaction

\begin{abstract}
Abstrak
Penelitian ini bertujuan untuk mengetahui dan menganalisis pengaruh kualitas pelayanan terhadap kepuasan pelanggan PT. Langit Membiru Wisata Bogor, untuk mengetahui seberapa besar pengaruh dan hubungan antara kualitas pelayanan dengan kepuasan pelanggan. Sampel yang digunakan adalah 100 responden yang diambil melalui uji-t atau wawancara, observasi, dan angket pada PT. Langit Membiru Wisata Bogor dan sumber data primer diolah dengan SPSS 25. Hasil uji t menunjukkan adanya pengaruh kualitas pelayanan terhadap kepuasan pelanggan, hal ini dibuktikan dengan variabel $(X)$ kualitas pelayanan dan variabel $(Y)$ kepuasan pelanggan memiliki nilai lebih kecil dari 0,05 yaitu $(0,00<0,05)$ hal ini terbukti dengan nilai pada uji t diperoleh thitung 91,624 > ttabel 5,293, sehingga dapat disimpulkan bahwa hipotesis dapat diterima.
\end{abstract}

Kata Kunci : Kualitas Pelayanan, Kepuasan Pelanggan

\section{PENDAHULUAN}

Pada era globalisasi ini, memberikan kepuasan kepada pelanggan merupakan suatu nilai mutlak karena hal tersebut menjadi suatu kunci dan juga keuntungan bagi penggiat usaha. Hal tersebut menjadi perhatian khusus bagi penyedia layanan jasa di Indonesia. Penyedia layanan jasa erat kaitannya dengan kepuasan pelanggan karena mereka memerlukan langkah dan juga strategi yang tepat agar dapat terus bersaing dan berkembang. Pesatnya perkembangan di era globalisasi ini, penyedia layanan jasa seperti travel agent menjadi suatu pilihan yang tepat bagi mereka yang tidak memiliki waktu luang untuk merencanakan liburan. Travel agent sendiri saat ini adalah salah satu bisnis penyedia jasa yang beberapa tahun terakhir ini terus berkembang pesat, baik dalam hal melayani tiket perjalanan maupun penyedia layanan penginapan.

Mengutip dari (Marketing Research Indonesia, 2015), sebanyak $71 \%$ para pengguna jasa mendapatkan informasi tentang travel agent dari rekomendasi kerabat maupun saudaranya, dan juga sebanyak $66 \%$ pengguna agen travel 
menilai jika harga bukanlah sesuatu hal yang sangat penting dalam memilih travel agent.

Dalam kasus ini, seorang pemimpin perusahaan harus menyediakan produk unggul dan terus berupaya untuk meningkatkan kualitas layanannya agar tingkat kepuasan konsumen terus meningkat. Beberapa travel agent di Indonesia semakin menyadari akan pentingnya kualitas pelayanan. Di era perkembangan teknologi yang sangat pesat saat ini, para penyedia layanan jasa memanfaatkan media teknologi informasi untuk berlomba-lomba memberikan kepuasan kepada pelanggan khususnya secara online. Beberapa travel agent menyediakan layanan CSO (Customer Service Officer) yang dimana menjadi sarana komunikasi para pelanggan untuk meminta bantuan dan berkeluh kesah terkait kualitas layanan yang telah di dapat dari travel agent tersebut. Customer Service Officer berperan penting sebagai garda terdepan untuk menjadi pendengar maupun penengah bagi suatu perusahaan untuk memberikan pelayanan yang baik terhadap customer.

Kualitas pelayanan menurut Sunyoto (2012) adalah suatu ukuran untuk menilai barang atau jasa telah mempunyai nilai guna seperti yang dikehendaki atau dengan kata lain suatu barang atau jasa dianggap telah memiliki kualitas apabila berfungsi atau mempunyai nilai guna yang diinginkan. PT. Langit Membiru Wisata merupakan perusahaan yang bergerak dibidang Pariwisata atau Tour \& Travel yang menargetkan customernya pada kaum muda atau Millenials. Dalam upaya meningkatkan layanan dan kepuasan pelanggan, PT. Langit Membiru Wisata memberikan beragam pilihan destinasi wisata menarik untuk para customer. Dan juga, menyediakan beberapa kemudahan bagi para pelanggan seperti kemudahan dalam memesan tiket perjalanan, rute wisata yang efisien dan cepat, memberikan pilihan perjalanan berwisata yang sesuai dengan budget pelanggan, serta didukung dengan Tour Guide yang handal. Hal tersebut menjadi perhatian travel agent ini agar dengan mudah dapat menjangkau customer dan memikat daya tarik customer untuk memilih PT. Langit Membiru Wisata.

\section{METODOLOGI PENELITIAN}

Objek penelitian penulisan yang digunakan dalam penelitian ini adalah desain penelitian deskriptif dengan pendekatan kuantitatif. Dalam penulisan jurnal ini, penulis melakukan penelitian di PT. Langit Membiru Wisata yang berlokasi di Bogor. Adapun metode yang digunakan dalam penelitian ini adalah dengan cara sampling jenuh atas populasi untuk mewakili seluruh populasi dan pengumpulan data menggunakan 
kuesioner. Metode yang digunakan yaitu metode kuantitatif dengan pengumpulan data melalui wawancara, observasi, dan kuesioner metode survei. Dalam penelitian ini populasi ditujukan bagi seluruh pelanggan PT. Langit Membiru Wisata di Bogor dengan jumlah 55 orang.

Dalam penelitian ini, penulis memakai teknik pengambilan sampel nonprobability sampling. Menurut Sugiyono (2019) metode nonprobability sampling (sampling jenuh) adalah teknik pemilihan sampel yang tidak didasarkan atas hukum probabilitas, oleh sebab itu tidak mengharuskan adanya peluang yang sama terhadap anggota populasi untuk dipilih, pemilihannya berdasarkan kriteriakriteria subjektif tertentu, namun kriterianya harus tetap jelas sehingga tidak menimbulkan bias. Yang perlu diperhatikan dalam penggunaan metode tak acak adalah bahwa teknik ini hanya digunakan bila tujuan penelitian sekedar mendeskripsikan sebuah objek penelitian tanpa melakukan generalisasi terhadap populasi. Selanjutnya pengambilan subjek penelitian menggunakan Confidence Level 95\% dengan tingkat kesalahan tidak lebih dari 10\%. Dapat disimpulkan sampel penelitian ini adalah pelanggan PT. Langit Membiru Wisata Bogor sebanyak 55 orang.

Teknik sampling yang digunakan dalam penelitian ini, menggunakan nonprobability sampling (sampling jenuh) sehingga jumlah sampel penelitian diperhitungkan menggunakan rumus dari Paul Leedy, sebagai berikut Arikunto (2012: 179):

\section{Keterangan:}

$\mathrm{N}=$ ukuran sampel

$\mathrm{P}=$ jumlah populasi

$\mathrm{E}=$ sampling error $(10 \%)$

$\mathrm{Z}=$ standar untuk keselahan yang dipilih

Dalam penelitian ini proses penyebaran kuesioner pada PT. Langit Membiru Wisata di Bogor dengan menggunakan link google form, dilakukan pada waktu siang di jam istirahat dan sore pada jam pulang kerja selama 2 minggu agar pengisian tidak terganggu pada saat aktivitas kerja. Setelah data penelitian ini diperoleh sesuai dengan populasi lalu penulis menginput data-data kedalam Microsoft Excel dengan mencocokkan data sesuaikan dengan skor nilai masing-masing setelah sudah diinput lalu copy paste kedalam SPSS 25 untuk memperoleh hasil data yang lebih akurat sesuai dengan Uji di SPSS versi 25.

Variabel ditetapkan sebagai konsep mengenai sifat yang terdapat pada subjek penelitian dan merupakan fokus dari kegiatan penelitian (Marpaung, 2021).

Data yang telah terkumpulkan melalui pembagian angket, kemudian peneliti mengolah kedalam bentuk kuantitatif, yaitu dengan menetapkan skor jawaban dari pertanyaan-pertanyaan yang 
dijawab oleh responden, dimana pemberian skor tersebut didasarkan pada ketentuan. Skala likert kemudian menskala individu yang bersangkutan dengan menambahkan bobot dari jawaban yang dipilih. Nilai ratarata masing-masing responden dapat dikelompokkan dalam kelas interval.

Sedangkan, Alat Analisis yang digunakan dalam penelitian ini adalah:

\section{Uji Validitas Data}

Uji validitas dimaksudkan untuk mengukur kualitas kuesioner yang digunakan sebagai instrument penelitian sehingga dapat dikatakan instrumen tersebut valid. Suatu kuesioner dikatakan valid jika pertanyaan pada kuesioner mampu mengungkapkan sesuatu yang akan diukur oleh kuesioner tersebut Ghozali (2013). Kriteria yang digunakan valid atau tidak valid adalah jika korelasi antara skor masing-masing butir pertanyaan dengan total skor mempunyai tingkat signifikan dibawah 0,05 maka butir pertanyaan tersebut tidak valid, dan jika dikorelasi skor masing-masing butir pertanyaan dengan total skor mempunyai tingkat signifikan diatas $\quad>0,05$ maka rumus sebagai berikut:

$$
\text { Rumus } \mathrm{r}_{\mathrm{xy}}=\frac{N \cdot \sum X Y-(\Sigma X)(\Sigma Y)}{\left.\sqrt{\left\{N \Sigma X^{2}\right.}-\left(\sum X\right)^{2}\right\}\left\{N \Sigma y^{2}-(\Sigma Y)^{2}\right\}}
$$

Keterangan:

rxy $=$ koefesien korelasi (validitas instrument)
$\mathrm{N} \quad$ = banyaknya butir pertanyaan

$\mathrm{X}=$ jumlah skor butir

$\mathrm{Y} \quad=$ skor total responden

$\mathrm{X} 2=$ jumlah kuadrat skor $\mathrm{X}$

Y2 = dalam pengujian validitas instrument menggunakan rumus korelasi product momen untuk mengetahui antara skor butir (X) dengan skor (Y).

Data diolah melalui program SPSS versi 25 , untuk membuktikan hasil analisis dapat dilihat pada output uji reliabilitas pada bagian corrected item total correlation. 1. Jika $r$ hitung positif serta $r$ hitung > $\mathrm{r}$ table maka butir atau variabel tersebut valid. 42 2. Jika $r$ hitung tidak positif dan $\mathrm{r}$ hitung $<\mathrm{r}$ table maka butir atau variabel tersebut tidak valid.

\section{Uji Reliabilitas}

Uji reliabilitas adalah alat untuk mengukur suatu kuesioner yang mempunyai indikator dari variabel atau konstruk. Ghozali mengemukakan sebuah kuesioner dinyatakan reliable jika jawaban seseorang terhadap pernyataan adalah konsisten atau stabil dari waktu ke waktu. Pengujian reliabilitas yang digunakan adalah one shot atau pengukuran sekali saja. Disini pengukurannya hanya sekali dan kemudian hasilnya dibandingkan dengan pertanyaan lain atau mengukur korelasi antara jawaban pertanyaan. SPSS memberikan fasilitas untuk mengukur reliabilitas dengan uji statistik Cronbach Alpha. Suatu konstruk 
atau variabel dikatakan reliabel jika memberikan Cronbach Alpha >0,06 atau lebih besar dari pada 0,06 .

Pengukuran reliabilitas dapat dilakukan dengan cara:

1. Repeated measure atau pengukuran ulang, dalam cara ini seseorang akan diberikan pertanyaan yang sama pada waktu yang berbeda, lalu kemudian dilihat apakah responden tetap konsisten dengan jawabannya.

2. One shot atau pengukuran sekali saja. Metode pengukuran hanya dilakukan sekali saja, lalu kemudian hasilnya dibandingkan dengan pertanyaanpertanyaan lain atau mengukur korelasi antar jawaban pertanyaan.

Uji reliabilitas itu dapat digunakan melalui program SPSS versi 25, yang akan memberikan fasilitas untuk mengukur nilai reliabilitas dengan menggunakan uji statistic cronbach alpha $(\alpha)$. Suatu konstruck atau variabel dikatakan reliable jika memberikan nilai cronbach alpha $(\alpha)>$ Ghozali (2018:46). Untuk menguji realibilitas instrument dilakukan dengan menggunakan rumus alpha cronbach dengan formula sebagai berikut:

$$
\mathrm{r} 11=\left(\frac{k}{k-1}\right)\left(1 \frac{\Sigma \alpha_{1}^{2}}{\alpha_{1}^{2}}\right)
$$

Keterangan:

$$
\begin{array}{ll}
\mathrm{r} 11 & =\text { koefesien reabilitas instrument } \\
\mathrm{k} & =\text { jumlah butir yang valid }
\end{array}
$$

$$
\begin{aligned}
& \Sigma \alpha_{1}^{2}=\text { jumlah varian skor tiap-tiap item } \\
& \alpha_{1}^{2}=\text { varian total }
\end{aligned}
$$

\section{Uji Analisi}

Dalam uji analisi terdapat uji korelasi, regresi dan determinasi berikut penjelasannya:

\subsection{Uji Korelasi}

Menurut Riadi (2014:14) korelasi pearson product moment adalah alat uji statistic parametric yang digunakan untuk menguji hubungan dua sampel acak, homogen dan terdistribusi normal. Secara sederhana, korelasi dapat diartikan sebagai hubungan. Namun ketika dikembangkan lebih jauh, korelasi tidak hanya dapat dipahami sebatas pengertian tersebut. Korelasi merupakan salah satu teknik analisis dalam statistic yang digunakan untuk mencari hubungan antara dua variabel yang bersifat kuantitatif.

Hubungan dua variabel tersebut dapat terjadi karena adanya hubungan sebab akibat atau dapat pula terjadi karena kebetulan saja. Dua variabel dikatakan berkorelasi apabila perubahan pada variabel yang 44 satu akan diikuti perubahan pada variabel yang lain secara tertentu dengan arah yang sama (korelasi positif) atau berlawanan (korelasi negatif). Cara termudah untuk melihat apakah dua variabel berhubungan adalah dengan melihat apakah mereka memiliki covarian. Pemahaman atas covarian menurut kita 
memahami konsep varian. Varian suatu variabel mewakili nilai rata perbedaan data variabel tersebut dengan nilai mean-nya. Adapun rumus pearson produk momen (r) adalah sebagai berikut :

$$
\mathrm{rxy}=\frac{n \sum x_{i} y_{i}-\left(\sum x_{i}\right)\left(\sum y_{i}\right)}{\sqrt{\left(n \sum x_{i}^{2}-\left(\sum x_{i}\right)^{2}\right\}-\left\{n \sum y_{i}^{2}-\left(\sum y_{i}\right)^{2}\right\}}}
$$

Keterangan:

rxy : koefisien korelasi person

$\mathrm{Xi}$ : variabel independen

$\mathrm{Yi} \quad$ : variabel dependen

$\mathrm{N} \quad$ : banyak sampel

Dari hasil yang diperoleh dari rumus diatas, dapat diketahui tingkat pengaruh variabel $\mathrm{x}$ dan variabel $\mathrm{y}$. pada hakikatnya nilai dapat bervariasi dari - 1 hingga +1 , atau secara matematis dapat ditulis menjadi $-1 \leq \leq+1$. Hasil dari perhitungan akan memberikan tiga alternatife, yaitu:

a. Bila $=0$ atau mendekati 0 , maka korelasi antara kedua variabel sangat lemah atau tidak terdapat hubungan antara variabel $\mathrm{x}$ terhadap variabel y.

b. Bila $=+1$ atau mendekati +1 , maka korelasi antara kedua variabel adalah kuat dan searah, dikatakan positif.

c. Bila $=-1$ atau mendekati -1 , maka korelasi antara kedua variabel adalah

kuat dan berlawanan arah, dikatakan negatif.

\subsection{Uji Determinasi}

Koefisien determinasi bertujuan untuk mengukur seberapa jauh kemampuan perhitungan dalam menerangkan variasi variabel terikat (dependen). Nilai koefisien determinasi adalah diantara nol dan satu. Pada pengujian hipotesis, hipotesis pertama koefisien determinasi dilihat dari besarnya nilai (R2) untuk mengetahui seberapa jauh variabel bebas yaitu kualitas pelayanan serta pengaruhnya terhadap produktifitas kerja karyawan. Nilai (R2) mempunyai interval antara 0 dan 1 . Jika nilai bernilai besar (mendeteksi 1) berarti variabel bebas dapat memberikan hampiran semua informasi yang dibutuhkan memprediksi variabel dependen. Sedangkan jika bernilai kecil berarti kemampuan variabel independen dalam menjelaskan variabel dependen amat terbatas. Secara umum koefisien determinasi untuk data silang (crossection) relatif rendah karena adanya variasi yang besar antara masing pengamatan, sedangkan untuk data runtun waktu (time series) biasanya mempunyai nilai koefisien determinasi yang tinggi (Ghozali 2018:97). Nilai koefisien determinasi yang kecil berarti kemampuan variabel independen dalam menjelaskan variasi variabel dependn itu terbatas. Nilai yang mendekati satu berarti variabel independen memberikan hampir semua informasi yang dibutuhkan untuk 
menjelaskan atau memprediksi variasi variabel dependen.

\section{Uji Regresi}

Regresi dipergunakan untuk mengelola hubungan antara dua variabel atau lebih, terutama untuk menelusuri pola hubungan yang modelnya belum diketahui dengan sempurna, atau untuk mengetahui bagaimana variabel independen berpengaruh terhadap variabel dependen dalam suatu fenomena yang kompleks. Persamaan regresi digunakan untuk menguji signifikan pengaruh Kualitas Pelayanan terhadap Kepuasan Pelanggan. Sugiyono (2019:299-300) Secara umum persamaan regresi

dapat dirumuskan sebagai berikut:

$$
\mathrm{Y}=\mathrm{a}+\mathrm{bX}
$$

Keterangan:

Y = Nilai yang diprediksikan

$\mathrm{a} \quad=$ Konstanta

$\mathrm{b} \quad=$ Koefisien regresi

$\mathrm{X}=$ Nilai variabel independen

\section{Uji hipotesis}

Uji hipotesis merupakan jawaban sementara terhadap rumusan masalah penelitian, uji yang dipergunakan adalah Uji t (parcial) berikut penjelasanya:

\subsection{Uji Statistik t}

Uji ini bertujuan untuk menguji pengaruh secara parcial antara variabel bebas terhadap variabel terikat dengan mengasumsikan variabel lain adalah konstan. Hasil pengujian terhadap tstatistik adalah:

1. Jika sig t tabel dan koefisien $\beta$ positif, maka hipotesis diterima.

2. Jika sig $\mathrm{t}$ tabel dan koefisien $\beta$ negatif, maka hipotesis ditolak.

Uji $\mathrm{t}$ digunakan untuk menguji apakah variabel independen secara parsial mempunyai pengaruh yang signifikan terhadap variabel dependen. Variabel independen dikatakan secara parsial berpengaruh signifikan terhadap variabel dependen apabila signifikan $($ sig) $<\alpha$ yaitu 0.05 , adapun tanda positif $(+)$ atau negatif (-) dari Beta dan $\mathrm{t}$ menunjukkan arah variabel. Apabila negative (-) maka variabel tersebut berpengaruh negative artinya menurunkan kualitas pelayanan dan apabila positif (+) maka variabel independen berpengaruh positif yang berarti kepuasan pelanggan.

\section{HASIL DAN PEMBAHASAN}

Untuk mendapatkangambaran mengenai karakteristik karyawan sebagai responden, berikut ini diuraikan pengelompokkan berdasarkan jenis kelamin responden, usia responden, pendidikan terakhir responden dan pekerjaan responden.data deskriptif dari penelitian yang telah dilakukan dengan judul pengaruh Kualitas Pelayanan Terhadap Kepuasan Pelanggan terhadap PT. Langit Membiru Wisata Bogor. 


\section{Uji Validitas Kualitas Pelayanan $X$}

Sugiyono (2016:267) Uji validitas merupakan derajat ketepatan antara data yang terjadi pada objek penelitian dengan daya yang dapat dilaporkan oleh peneliti". Dalam penelitian kuantitatif, untuk mendapatkan data yang valid, reliable dan obyektif. Penelitian dilakukan dengan menggunakan instrumen yang valid dan reliable, maka digunakan pada sampel yang mendekati jumlah populasi dan pengumpulan serta analisis data yang digunakan dengan cara yang benar.

\section{Tabel 1}

\section{Hasil Uji Validitas Variabel Kualitas}

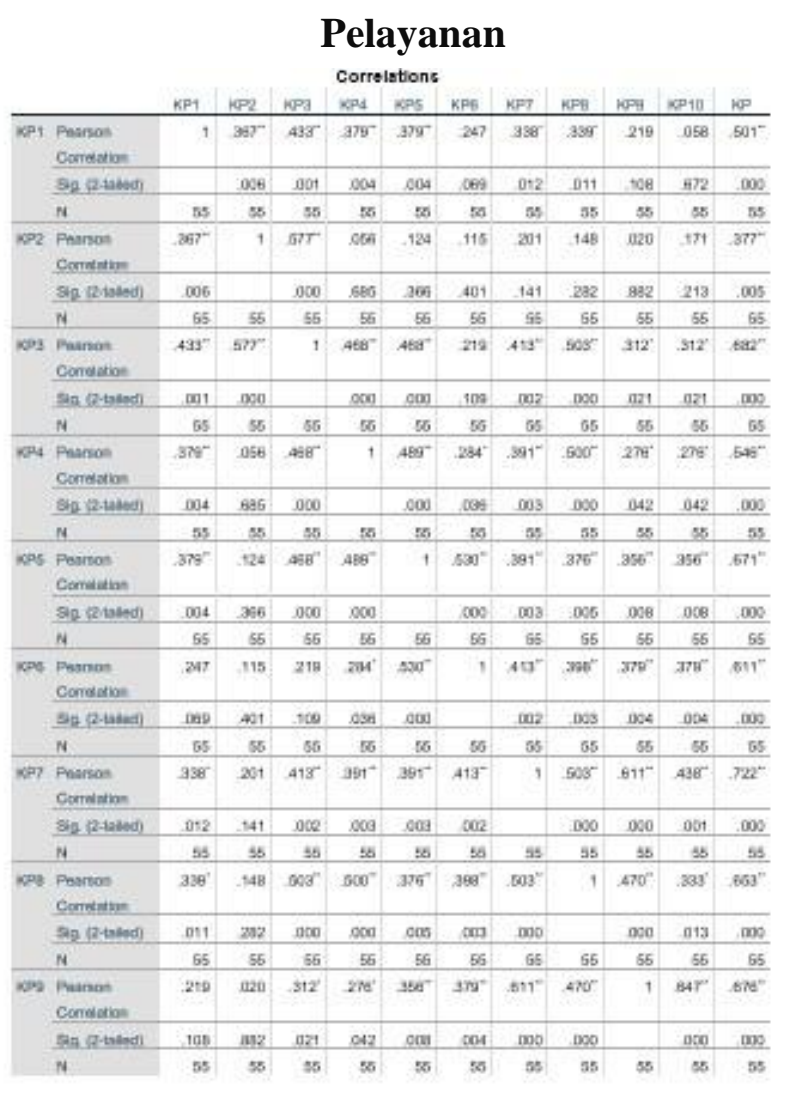

statistic dari data tersebut dapat digunakan untuk mengukur penelitian ini dengan tepat dan akurat.

\section{Tabel 1.1}

\section{Hasil Uji Validitas Variabel Produktivitas Kerja}

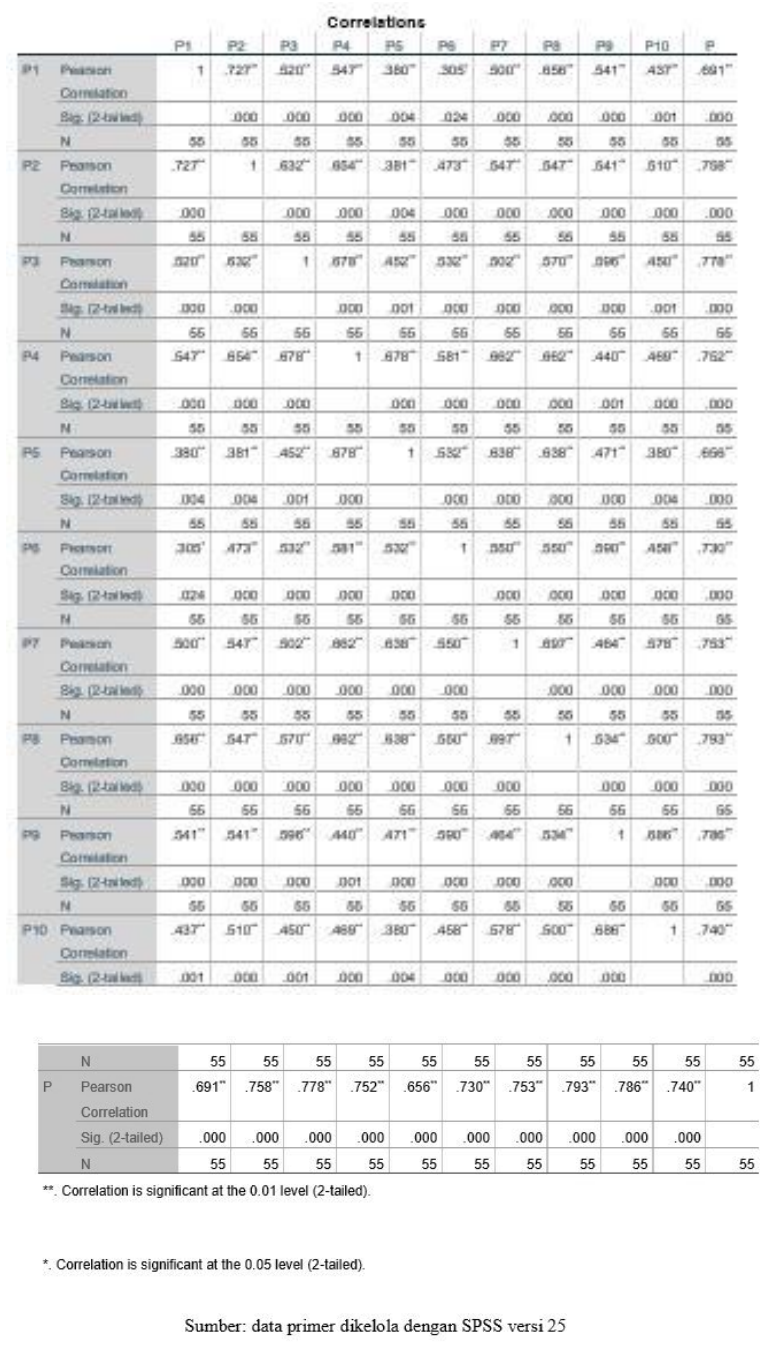

Dari tabel 4.2 menunjukkan bahwa seluruh butir pernyataan pada variabel kepuasan pelanggan (y) adalah valid, 10 item pernyataan adalah valid, karena nilai rhitung untuk setiap item pernyataan lebih besar dibandingkan r-tabel sebesar 0,279 (taraf signifikan 5\% dan $\mathrm{n}=55$ ). Dengan demikian maka dari 10 item dalam instrument pernyataan validitas atau secara statistik dari data tersebut dapat digunakan 
untuk mengukur penelitian ini dengan tepat dan akurat.

\section{Uji Reliabilitas (konsisten)}

Tabel 2

Hasil Uji Reliabilitas Kualitas

\section{Pelayanan dan Kepuasan Pelanggan}

Reliability Statistics

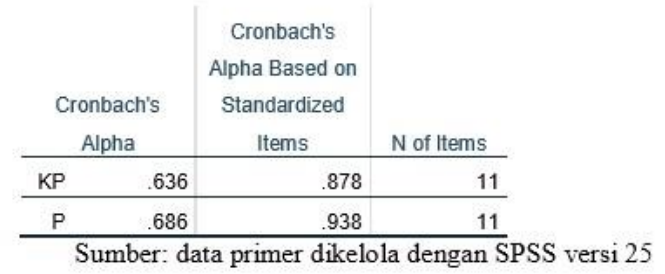

Berdasarkan tabel 2 hasil dari penghitungan SPSS variabel Kepuasan Pelayanan sebesar 0.636 variabel Kepuasan pelanggan 0,636 menunjukkan bahwa instrumen untuk setiap variabel penelitian adalah reliabel atau konsisten karena jika nilai cronbach alpha $>0.6$ maka reliabel atau konsisten.

\section{Hasil Uji Korelasi}

\section{Tabel 3}

\section{Hasil Uji Korelasi}

\begin{tabular}{llrr}
\multicolumn{3}{c}{ Correlations } \\
& \multicolumn{1}{c}{ KP } & \multicolumn{1}{c}{ P } \\
\hline KP & Pearson Correlation & 1 & $.732^{*}$ \\
\cline { 2 - 4 } & Sig. (2-tailed) & & .000 \\
\cline { 2 - 4 } & N & 55 & 55 \\
\hline P & Pearson Correlation & $.732^{*}$ & 1 \\
\hline & Sig. (2-tailed) & .000 & \\
\hline N & 55 & 55 \\
\hline
\end{tabular}

Sumber : Data primer dikelola dengan SPSS versi 25

Berdasarkan tabel diatas hubungan variabel Kualitas Pelayanan terhadap Kepuasan Pelanggan sigifikan karena angka signifikan sebesar 0,000>0,01. Arah korelasi dapat dilihat dari angka koefisien hasilnya positif atau negatif. Sesuai dengan hasil analisis, koefisien korelasi jauh bernilai positif yaitu 0,732 maka korelasi kedua variabel bersifat searah.

4. Hasil dan Pembahasan Uji

\section{Determinasi}

Tabel 4

Hasil Uji Determinasi

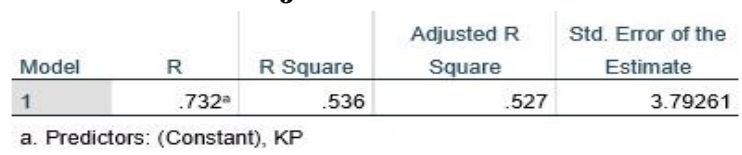

Sumber : Data primer dikelola dengan SPSS versi 25

Dilihat dari table 4.11 hasil output spss diatas didapatkan nilai $\mathrm{R}$ (koefisien determinasi) 0,536 yang artinya pengaruh Kualitas Pelayanan (independen) adalah sebesar 53,6\% ini menunjukkan bahwa nilai $\mathrm{R}$ hampir mencapai angka 1 dan variabel bebas dapat memberikan hampir semua informasi yang dibutuhkan untuk memprediksi variabel terikat (dependen).

\section{Hasil dan Pembahasan Uji Regresi}

Tabel 5

\section{Hasil Uji Regresi}

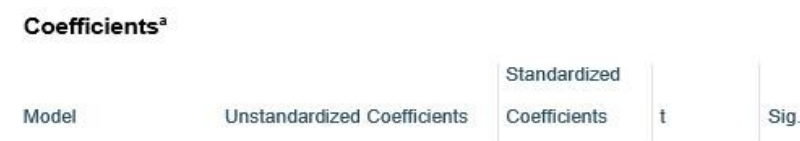

\begin{tabular}{|c|c|c|c|c|c|c|}
\hline & & B & Std. Error & Beta & & \\
\hline \multirow[t]{2}{*}{1} & (Constant) & 15.460 & 6.397 & & 2.417 & .019 \\
\hline & KP & .762 & .097 & .732 & 7.821 & .000 \\
\hline
\end{tabular}

Sumber : data primer dikelola SPSS versi 25

Jika dilihat dari persamaan regresi di atas dapat dijelaskan nilai konstanta 
sebesar 15,460 mengandung arti bahwa nilai konsisten variabel-variabel Kepuasan Pelanggan sebesar 15,460. Dan nilai koefisien regresi $\mathrm{X}$ sebesar 0,762 menyatakan bahwa setiap penambahan $1 \%$ nilai Kualitas Pelayanan maka nilai kepuasan pelanggan bertambah sebesar 0,762. Dengan nilai signifikan adalah 0,000 ini menunjukkan bahwa nilai signifikan lebih dari 0,05 sehingga dapat disimpulkan bahwa variabel Kualitas Pelayanan berpengaruh terhadap variabel Kepuasan Pelanggan.

\section{Hasil dan Pembahasan Uji Hipotesis}

Tabel 6

\section{Hasil Uji t dari SPSS versi 25}

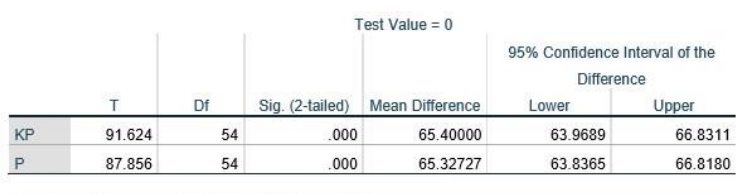

Sumber : data primer dikelola SPSS versi 25

Dari tabel di atas dapat dilihat bahwa nilai signifikan adalah sebesar 0,000. Sesuai dengan dasar pengambilan keputusan jika nilai signifikan lebih kecil dari pada nilai probabilitas $(\operatorname{sig}<0,05)$ maka dapat disimpulkan bahwa hipotesis diterima. Artinya ada pengaruh Kualitas Pelayanan (X) terhadap Kepuasan Pelanggan (Y).

\section{KESIMPULAN}

Setelah penulis melakukan penelitian mengenai Pengaruh Kualitas Pelayanan Terhadap Kepuasan Pelanggan PT. Langit Membiru Wisata Bogor.
Dengan ini penulis menyimpulkan bahwa berdasarkan hasil Kualitas Pelayanan (x) dan variabel Kepuasan Pelanggan (y) memiliki nilai signifikan lebih kecil dari 0,05 yaitu $(0,00<0,05)$. Maka hubungan tersebut dinyatakan linier dan terdapat hubungan yang signifikan. Kualitas Pelayanan tersebut dapat diambil kesimpulan bahwa kualitas pelayanan adalah segala bentuk aktivitas yang dilakukan oleh perusahaan guna memenuhi harapan konsumen. Pelayanan dalam hal ini diartikan sebagai jasa atau service yang disampaikan oleh pemilik jasa yang berupa kemudahan, kecepatan, hubungan, kemampuan dan keramahtamahan yang ditujukan melalui sikap dan sifat dalam memberikan pelayanan untuk kepuasan konsumen. Kualitas pelayanan (service quality) dapat diketahui dengan cara membandingkan persepsi para konsumen atas pelayanan yang nyata-nyata mereka terima / peroleh dengan pelayanan yang sesungguhnya mereka harapkan/inginkan terhadap atribut-atribut pelayanan suatu perusahaan.

Sedangkan kepuasan pelanggan adalah Kepuasan pelanggan lebih mengarah pada perasaan senang atau kecewa dari seseorang yang muncul setelah membandingkan produk maupun jasa dari apa yang mereka pikirkan dengan apa yang merekan harapkan. Dari pendapat tersebut, maka kita dapat mengambil kesimpulan 
jika pelanggan merasa puas maka kemungkinannya pelanggan ini akan bertahan dengan produk Anda dalam waktu lama. Begitu pula sebaliknya. Kepuasan pelanggan juga menjadi salah satu tolok ukur keberhasilan yang juga berdampak pada tingkat penjualan.

\section{Saran}

Berdasarkan hasil penelitian dan pembahasan serta kesimpulan yang telah diuraikan sebelumnya, maka penulis mengemukakan beberapa saran yang dapat dijadikan bahan masukan bagi PT. Langit Membiru Wisata Bogor yang mudahmudahan dapat diambil manfaatnya dalam rangka meningkatkan pengaru kualitas pelayanan terhadap kepuasan pelanggan. Adapun beberapa saran yang dikemukakan adalah sebagai berikut:

1. Melihat hasil penelitian tentang Kualitas Pelayanan bahwa PT. Langit Membiru

\section{REFERENCES}

Ghozali. 2015. Metode penelitian kualitatif dan kuantitatif. Ar-Ruzz Media Yogyakarta

Nazir. 2015. Metode penelitian kualitatif dan kuantitatif. Karya Adhika Utama Bandung

Moenir, H.A.S. (2010). Manajemen Pelayanan Umum di Indonesia. Jakarta : Bumi Aksara
Wisata Bogor memberikan kualitas pelayanan tentang memudahkan cara memesan tiket travel, sarana dan transportasi, kerjasama hotel atau villa serta tour guide yang berpengalaman merupakan strategi dari perusahaan agar pelanggan merasa lebih mudah dan nyaman dalam menggunakan pelayanan perusahaan tour dan travel. Khususnya dalam hal membooking atau memesan tiket harusnya mengikuti sesuai dengan perkembangan zaman yaitu dengan menggunakan website ataupun platform lainya seperti bergabung dengan traveloka dll mungkin itu saja saran dari penulis.

2. Sedangkan Kepuasan Pelanggan yang harus diperhatikan oleh perusahaan adalah harus disesuaikan dengan kualitas layanan dan budget pelanggan dengan layanan yang sama yang diberikan travel

Nazir Mohammad, 1999. Metode Penelitian. Jakarta: Ghalia Indonesia.

Marpaung, N. N. (2021). Pengaruh Citra Merek Dan Kualitas Produk Terhadap Minat Beli Sepatu Ando (Studi Kasus Di Kota Bekasi 2020). PARAMETER, 5(2), 27-40.

https://doi.org/10.37751/parameter.v5

i2. 147 
Rahmayanty, Nina (2014). Manajemen

Pelayanan Prima. Yogyakarta:

Graha Ilmu.

Sugiyono, (2011). Metode Penelitian Bisnis. Bandung:

CV.Alfabeta.

Tjiptono, Fandy. (2010). Pemasaran strategik. Penerbit Andi, Yogyakarta.

Tjiptono , Fandy dan Gregorius Chandra. (2012). Pemasaran Strategik. Yogyakarta,

ANDI. Zulian Yamit. (2012). Manajemen Kualitas Produk \& Jasa. Yogyakarta: Ekonisia.

SPSS Indonesia. 2019. Cara melakukan uji $\mathrm{t}$ parsial dalam analisis regresi dengan spss.

Sudarsana, Cakra. 2016. 116 kiat mempertajam kinerja anak buah. Yogyakarta:

Laksana Sugiyono. 2013. Metode penelitian kuantitatif kualitatif dan R\&D. Bandung:

Alfabeta Sugiyono. 2016. Metode Penelitian Kuantitatif, Kualitatif, dan R\&D. Bandung: Alfabeta, cv

Sugiyono. 2017. Metode penelitian kuantitatif, kualitatif, dan R\&D. Bandung: Alfabeta

Sugiyono. 2019. Metode penelitian kuantitatif. Bandung:

Alfabeta,cv
Sunyoto, Danang. 2015. Penelitian Sumber Daya Manusia. Jakarta: PT. Buku Seru

Ghozali, Imam. 2018. Aplikasi analisis multivariate dengan program IBM SPSS 25 Edisi $9 . \quad$ Semarang: Badan Penerbit Universitas Diponegoro

Aryani, Dwi \& Febrina Rosinta, (2010). Pengaruh Kualitas Layanan terhadap Kepuasan Pelanggan dalam Membentuk Loyalitas Pelanggan. Jurnal limn Administrasi dan Organisasi, 17(2), 114-126

Atmaja, Aditama Kusuma. (2011). Analisis Pengaruh Kualitas Pelayanan Terhadap Kepuasan Pelanggan (Studi Pada Tiket Garuda Di PT Fatah Fantastic Tour Travel Bogor). Skripsi Fakultas Ekonomi, Universitas Diponegoro

Kotler Philip and Kevin Keller, 2007.Manajemen Pemasaran Edisi 12. Jilid pertama dan Kedua. PT. Indeks : Jakarta 